\title{
PENGETAHUAN DAN SIKAP PEDAGANG JAJANAN ANAK SEKOLAH TERHADAP PENGGUNAAN FORMALIN DAN BORAKS DI SD NEGERI WILAYAH PEDURUNGAN KOTA SEMARANG
}

\section{THE KNOWLEDGE AND ATTITUDES OF SCHOOL CHILDREN'S TRADERS ON THE USE OF FORMALIN AND BORAKS IN THE STATE AREA OF EDUCATION AREA}

\author{
Luthfiyah Nur Safitri ${ }^{1}$, Dyah Nur Subandriani ${ }^{2}$, Astidio Noviardhi ${ }^{3}$, Arintina Rahayuni ${ }^{4}$, Ana Yuliah \\ Rahmawati $^{5}$
}

\begin{abstract}
Background : Chemical material such as formalin and borax should notfound in food because it can cause nausea, stomachache, vomiting, bloody defecation. But with reason to reduce production costs, take profits and extend the shelf life, many producers who still use these materials. This is due to lack of knowledge and the attitude of the producer indifferent to food security.
\end{abstract}

Objective : Knowing the relationship between knowledge and attitudes of schoolboy snack vendors to the use of formaldehyde and borax in children's snacks in public elementary schools in the urban area of pedurungan Semarang city.

Method : This research is a descriptive analytic study with cross sectional design, a total sample of 20 samples of schoolchildren's street vendors. In this study the measuring instruments used were questionnaires and interviews. The test used is Fisher's exact.

Results : Trader's knowledge is mostly good (80\%)and the attitude of traders mostly supports (60\%). The bivariate test results obtained $p$ value $>0.05$ so there is no relationship between knowledge and attitudes of street food traders to the use of formalin and borax.

Conclusion: The use of formalin and borax is not caused by the knowledge and attitudes of traders related to food security.

Keywords : Streetfood vendors, knowledge and attitudes, formalin, borax

\section{ABSTRAK}

Latar Belakang: Bahan kimia seperti formalin dan boraks tidak seharusnya terdapat dalam makanan karena dapat menyebabkan mual, sakit perut, muntah, buang air besar berdarah.Namun dengan alasan untuk menekan biaya produksi, mengambil keuntungan dan memperpanjang masa simpan, banyak produsen yang masih menggunakan bahan-bahan tersebut. Hal itu dapat disebabkan oleh pengetahuan yang kurang dan sikap produsen yang acuh terkait keamanan pangan.

Tujuan:Mengetahui hubungan pengetahuan dan sikap pedagang jajanan anak sekolah terhadap penggunaan formalin dan boraks pada jajanan anak di SD Negeri wilayah Pedurungan.

Metode: Penelitian ini merupakan jenis penelitian deskriptif analitik dengan rancangan cross sectional, jumlah sampel sebanyak 20 sampel pedagang jajanan anak sekolah di 12 SD Negeri Wilayah Pedurungan Kota Semarang. Pada penelitian ini alat ukur yang digunakan adalah kuesioner dan wawancara. Uji yang digunakan adalah Fisher's exact.

Hasil: Pengetahuan pedagang sebagian besar baik (80\%) dan sikap pedagang sebagian besar mendukung (60\%). Hasil uji bivariat didapatkan nilai $p$ value $>0,05$ maka tidak terdapat hubungan antara pengetahuan dan sikap pedagang makanan jajanan terhadap penggunaan formalin dan boraks.

Kesimpulan:Penggunaan formalin dan boraks bukan disebabkan karena pengetahuan dan sikap pedagang terkait keamanan pangan. 


\section{PENDAHULUAN}

Keamanan pangan merupakan syarat penting yang harus melekat pada pangan yang hendak dikonsumsi oleh semua masyarakat Indonesia dan merupakan suatu hal yang harus diperhatikan karena dapat berdampak pada kesehatan, baik bagi anak-anak maupun orang dewasa. Keamanan pangan bukan hanya merupakan isu dunia tapi juga menyangkut kepedulian individu. Jaminan akan keamanan pangan adalah merupakan hak asasi konsumen. Pangan termasuk kebutuhan dasar terpenting dan sangat esensial dalam kehidupan manusia ${ }^{1}$.

Badan Pengawas Obat dan Makanan (BPOM) RI melaporkan bahwa setiap tahun permasalahan keamanan pangan menyebabkan kematian sebayak 2.500 orang dan sebanyak 411.500 orang sakit. Satu hal yang lebih mengkhawatirkan adalah permasalahan ini terjadi pada Industri Kecil Menengah (IKM), dan IKM pangan ini memiliki kuantitatif paling besar. Masyarakat Indonesia terpapar dengan makanan yang potensial berbahaya, seperti penambahan bahan tambahan pangan yang berbahaya. Sebagai contoh, penggunaan pewarna tekstil untuk makanan, penggunaan bahan kimia bukan aditif makanan sebagai pengawet, contohnya formalin, boraks, terusi dan sebagainya. Hal tersebut menunjukan rendahnya tingkat keamanan pangan yang ada di Indonesia ${ }^{2}$.

Beberapa hal yang dapat menyebabkan penggunaan bahan kimia berbahaya dalam makanan antara lain : (1) ketidaktahuan produsen makanan, (2) kurang ketatnya pengawasan, (3) harga aditif makanan yang relatif masih mahal. Sehingga kasus-kasus semacam diatas timbul dari produk-produk industri kecil ataupun rumah tangga ${ }^{3}$.

Bahan kimia berbahaya formalin tidak diperkenankan ada dalam makanan maupun minuman, karena dalam jangka panjang dapat memicu perkembangan sel-sel kanker. Dan jika tertelan akan dapat mengakibatkan mual, sakit perut akut yang disertai muntah-muntah, buang air besar berdarah ${ }^{4}$. Bahan kimia boraks juga tidak diperbolehkan dikonsumsi karena boraks bersifat karsinogenik. Selain itu boraks juga dapat menyebabkan gangguan pada bayi, gangguan proses reproduksi, menimbulkan iritasi pada lambung, dan atau menyebabkan gangguan pada ginjal, hati, dan testis ${ }^{5}$.

Menurut penelitian Novita dan Adriyani pada tahun 2008 penyalahgunaan bahan kimia berbahaya seperti formalin dan boraks oleh produsen pangan jajanan disebabkan karena tingkat pengetahuan produsen yang rendah mengenai keamanan pangan jajanan ${ }^{5}$.

Karena pengawasan yang rendah dari BPOM terhadap peredaran bahan kimia berbahaya sehingga memudahkan akses pedagang dalam mendapatkannya dan dengan alasan untuk menekan biaya produksi, mengambil keuntungan dan memperpanjang masa simpan, banyak produsen yang masih menggunakan bahan-bahan tersebut.

Tujuan penelitian ini yaitu untuk mengetahui hubungan pengetahuan dan sikap pedagang jajanan anak sekolah terhadap penggunaan formalin dan boraks pada jajanan anak di SD Negeri wilayah Pedurungan.

\section{METODE}

Penelitian ini merupakan penelitian bidang gizi institusi yang menekankan pada keamanan pangan. Termasuk dalam jenis penelitian deskriptif analitik yang bertujuan mengetahui hubungan antara pengetahuan dan sikap pedagang jajanan anak sekolah dengan penggunaan formalin dan boraks.Rancangan penelitian ini adalah cross sectional dengan metode survey, karena semua variabel dikumpulkan pada waktu yang sama. Jumlah pengulangan dilakukan sebanyak satu kali dan total sampel yang diteliti berjumlah 20 sampel. Sampel penelitian dipilih dengan cara acak kelompok atau cluster ${ }^{6}$. Dari 32 SD Negeri di wilayah Pedurungan dipilih sejumlah SD Negeri sebagai kelompok sampel, ditentukan dengan menggunakan rumus dari S.Lemeshow (1997) ${ }^{7}$ dan diperoleh hasil 12 SD Negeri sebagai kelompok sampel.

Dengan cara tesebut diperoleh namanama SD Negeri yang dijadikan kelompok sampel yaitu SDN Pedurungan Kidul 01, SDN Pedurungan Kidul 02, SDN Pedurungan Kidul 03, SDN Pedurungan Lor 01, SDN Pedurungan Tengah 02, SDN Plamongan Sari 01, SDN Tlogosari Kulon 01, SDN Tlogosari Kulon 03, SDN Tlogosari Kulon 04, SDN Tlogosari Kulon 06, SDN Palebon 01, SDN Palebon 03. Yang menjadi sampel penelitian ini adalah pedagang dan produsen makanan jajanan anak sekolah (meliputi sempol ayam, cilor, bakso, tempura, cilok, somay, pempek, cireng dan batagor) yang dijual di SD Negeri yang menjadi kelompok sampel di wilayah Pedurungan Kota Semarang.

Pengukuran pengetahuan dan sikap pedagang dilakukan dengan metode wawancara menggunakan instrumen yang meliputi formulir informed concern, formulir identitas dan 
karakteristik, kuesioner pengetahuan tentang keamanan pangan, kuesioner sikap tentang keamanan pangan. Pengolahan data dilakukan dengan uji Fisher's Exact dengan komputer ${ }^{6}$.

\section{HASIL DAN PEMBAHASAN}

Penelitian ini dilakukan di 12 SD Negeri wilayah Pedurungan kota Semarang. Dan mendapatkan 9 jenis makanan jajanan yaitu sempol ayam, cilor, bakso, tempura, cilok, somay, pempek, cireng dan batagor.

\section{A. Karakteristik Responden}

Tabel 1. Distribusi Karakteristik Responden

\begin{tabular}{|c|c|c|c|}
\hline \multicolumn{2}{|c|}{ Variabel } & $\mathbf{n}$ & $\%$ \\
\hline \multirow[t]{2}{*}{ Umur } & 15-64 tahun & 19 & 95 \\
\hline & $>64$ tahun & 1 & 5 \\
\hline Jenis Kelamin & Laki-laki & 20 & 100 \\
\hline \multirow[t]{4}{*}{ Tingkat Pendidikan } & Tidak Sekolah & 2 & 10 \\
\hline & $\begin{array}{l}\text { Tamat SD } \\
\end{array}$ & 5 & 25 \\
\hline & Tamat SMP & 7 & 35 \\
\hline & Tamat SMA & 6 & 30 \\
\hline Keikutsertaan Penyuluhan & Pernah & 14 & 70 \\
\hline Keamanan Pangan & Tidak Pernah & 6 & 30 \\
\hline
\end{tabular}

Berdasarkan tabel 1, distribusi responden menurut umur yang termasuk dalam umur produktif sebanyak 19 orang (95\%). Seluruh responden berjenis kelamin lakilaki. Sebagian besar responden menempuh pendidikan dasar yaitu sebesar $70 \%$. Sebagian besar responden tidak pernah mengikuti penyuluhan sebanyak 14 orang (70\%). Hal ini menunjukkan bahwa sebagian besar responden belum sepenuhnya terpapar mengenai kemanan pangan.

B. Pengetahuan Pedagang Jajanan Anak Sekolah tentang Keamanan Pangan

Berdasarkan hasil penilaian
pengetahuan dengan menggunakan kuesioner menunjukkan bahwa skor pengetahuan minimum 28,5 , maksimum 100 , dan rata-rata 68,1 . Distribusi frekuensi pedagang menurut kategori tingkat pengetahuan keamanan pangan terdapat pada tabel 2 .

Tabel 2. Distribusi Frekuensi Pengetahuan Pedagang Jajanan Anak Sekolah tentang Keamanan Pangan

\begin{tabular}{ccc}
\hline Kategori Pengetahuan & Frekuensi & $\%$ \\
\hline Kurang Baik & 4 & 20 \\
\hline Baik & 16 & 80 \\
\hline Total & 20 & 100 \\
\hline
\end{tabular}

Tabel 2 menunjukkan bahwa pedagang jajanan anak sekolah yang yang memiliki pengetahuan kurang berjumlah 4 orang $(20 \%)$ dengan rata-rata skor $<50 \%$.

Berdasarkan jawaban kuesioner perihal jenis bahan tambahan makanan (BTM) yang diperbolehkan, fungsi asli boraks dan formalin, penggunaan formalin dan boraks dalam makanan sebagian besar responden menjawab salah.

Berdasarkan jawaban kuesioner perihal pengertian dan fungsi bahan tambahan pangan, jenis bahan kimia yang dilarang untuk makanan, dampak dari penggunaan bahan tambahan yang dilarang untuk pangan sebagian besar pedagang menjawab benar.

C. Sikap Pedagang Jajanan Anak Sekolah tentang Keamanan Pangan

Hasil kuesioner sikap pedagang jajanan anak diperoleh skor terendah yaitu 1,57 , sedangkan skor tertinggi yaitu 2,00 dengan rata-rata nilai skor adalah 1,83. Distribusi frekuensi pedagang jajanan anak sekolah berdasarkan sikap tentang keamanan pangan dapat dilihat pada tabel 3 .

Tabel 3. Distribusi Frekuensi Sikap Pedagang Jajanan Anak Sekolah tentang Keamanan Pangan

\begin{tabular}{ccc}
\hline Kategori Sikap & Frekuensi & $\%$ \\
\hline Mendukung & 12 & 60 \\
\hline Tidak Mendukung & 8 & 40 \\
\hline Total & 20 & 100 \\
\hline
\end{tabular}

Tabel 3 menunjukkan bahwa pedagang jajanan anak sekolah yang memiliki sikap yang mendukung sebesar (60\%). Hal ini menunjukan bahwa sebagian besar pedagang jajanan anak sekolah wilayah Pedurungan memiliki sikap yang mendukung terhadap keamanan pangan.

Berdasarkan jawaban kuesioner perihal pernyataan tentang bleng boleh digunakan dalam makanan sebagian besar responden menyatakan setuju. Hal ini kemungkinan terjadi karena masyarakat umumnya tidak mengetahui bahwa bleng merupakan bentuk tidak murni dari boraks. Dengan demikian bleng merupakan bahan kimia yang berbahaya.

D. Hasil Identifikasi Jenis-Jenis Makanan Jajanan Anak yang Mengandung Formalin dan Boraks

Hasil identifikasi jenis-jenis makanan jajanan anak sekolah di SD Negeri wilayah Pedurungan Kota Semarang yang mengandung formalin dan boraks. Dari hasil penelitian, didapat hasil bahwa dari 21 sampel, semua sampel tidak ada yang mengandung formalin. Terdapat 3 sampel yang positif mengandung boraks. Hasil identifikasi makanan jajanan yang 
mengandung formalin dan boraks terpapar pada tabel 4.

Tabel 4. Hasil Identifikasi Makanan Jajanan Anak yang Mengandung Boraks di SD Negeri wilayah Pedurungan tahun 2018

\begin{tabular}{cccccc}
\hline \multirow{2}{*}{ No } & \multirow{2}{*}{ Jenis Makanan Jajanan } & Frekuensi & \multicolumn{3}{c}{ Persentase (\%) } \\
\cline { 3 - 6 } & & Positif & Negatif & Positif & Negatif \\
\hline $\mathbf{1}$ & Sempol Ayam & 0 & 1 & 0 & 100 \\
$\mathbf{2}$ & Cilor & 1 & 3 & 25 & 75 \\
$\mathbf{3}$ & Bakso & 0 & 5 & 0 & 100 \\
$\mathbf{4}$ & Tempura & 1 & 0 & 100 & 0 \\
$\mathbf{5}$ & Cilok & 0 & 3 & 0 & 100 \\
$\mathbf{6}$ & Siomay & 1 & 1 & 50 & 50 \\
$\mathbf{7}$ & Pempek & 0 & 2 & 0 & 100 \\
$\mathbf{8}$ & Cireng & 0 & 1 & 0 & 100 \\
$\mathbf{9}$ & Batagor & 0 & 2 & 0 & 100 \\
& Jumlah & 3 & 18 & 14.3 & 85.7 \\
\hline
\end{tabular}

Hasil identifikasi makanan jajanan anak terhadap penggunaan boraks pada tabel 5 diketahui bahwa $14,3 \%$ hasil positif yang berarti terdapat 3 makanan jajanan yang terdapat boraks. Makanan jajanan tersebut adalah tempura, cilor dan somay. Hasil ini tidak sejalan dengan Permenkes no. 722 yang menyatakan boraks sebagai bahan berbahaya dan dilarang untuk makanan. Karena mengonsumsi boraks dapat menyebabkan mual, nyeri perut bagian atas, diare, demam,kerusakan ginjal, hati dan testis ${ }^{8}$.

\section{E. Hubungan Pengetahuan Keamanan Pangan} terhadap Penggunaan Formalin dan Boraks

Pengujian seluruh sampel terhadap penggunaan formalin menunjukkan hasil negatif. Hasil ini sejalan dengan anjuran pemerintah yang melarang penggunaan formalin pada makanan. Hal tersebut tertuang dalam Peraturan Bersama Menteri Dalam Negeri Republik Indonesia dan Kepala Badan Pengawas Obat Dan Makanan Republik Indonesia Nomor: 43 Tahun 2013 dan Nomor: 2 Tahun 2013 tentang Pengawasan Bahan Berbahaya Yang Disalahgunakan Dalam Pangan. Pengawasan terhadap peredaran formalin telah dilakukan oleh pemerintahkarena formalin termasuk salah satu bahan berbahaya yang disalahgunakan dalam makanan. Formalin tidak bisa diperjual belikan dengan mudah.

Bahan kimia berbahaya yang masih ditemukan pada makanan jajanan adalah boraks. Meskipun peredaran boraks juga termasuk dalam pengawasan bahan berbahaya yang disalahgunakan untuk pangan, masih terdapat sampel yang positif mengandung boraks. Padahal menurut peraturan Menteri Kesehatan No. 722/MenKes/Per/IX/88 boraks dinyatakan sebagai bahan berbahaya dan dilarang untuk digunakan dalam pembuatan makanan, karena boraks merupakan racun bagi semua sel sehingga dapat berpengaruh buruk bagi kesehatan manusia ${ }^{9}$.

Pembelian boraks di toko bahan kimia harus melalui prosedur yang sama seperti ketika membeli formalin. Namun di pasar tradisional, untuk membeli bleng yang merupakan bentuk tidak murni dari boraks sangat mudah karena bleng masih dijual bebas di pasar tradisonal.

Hasil pengujian statitistik hubungan antara pengetahuan pedagang jajanan anak dan penggunaan formalin dan boraks dapat dilihat secara rinci pada tabel 5 .

Tabel 5. Hasil Analisis Penggunaan Formalin dan Boraks Menurut Pengetahuan Pedagang Jajanan Anak di SD Negeri wilayah Pedurungan Tahun 2018

\begin{tabular}{|c|c|c|c|c|c|c|c|}
\hline \multirow{4}{*}{$\begin{array}{l}\text { Pengetahuan } \\
\text { Pedagang Jajanan } \\
\text { Anak }\end{array}$} & \multicolumn{4}{|c|}{$\begin{array}{c}\text { Penggunaan Formalin dan } \\
\text { Boraks }\end{array}$} & \multirow{3}{*}{\multicolumn{2}{|c|}{ Total }} & \multirow{4}{*}{ p } \\
\hline & \multirow{2}{*}{\multicolumn{2}{|c|}{ Tidak Ada }} & \multirow{2}{*}{\multicolumn{2}{|c|}{ Ada }} & & & \\
\hline & & & & & & & \\
\hline & $\mathrm{n}$ & $\%$ & $\mathbf{n}$ & $\%$ & $\mathrm{n}$ & $\%$ & \\
\hline Kurang Baik & 3 & $75 \%$ & 1 & $25 \%$ & 4 & $100 \%$ & \\
\hline Baik & 14 & $87,5 \%$ & 2 & $12,5 \%$ & 16 & $100 \%$ & 0,509 \\
\hline Total & 17 & $85 \%$ & 3 & $15 \%$ & 20 & $100 \%$ & \\
\hline
\end{tabular}

Tabel 5 menunjukan bahwa pedagang dengan pengetahuan keamanan pangan dalam kategori kurang baik sebagian besar tidak menggunakan formalin dan boraks (75\%). Sedangkan pedagang dengan kategori pengetahuan kurang baik yang menggunakan bahan kimia berbahaya yaitu boraks sebanyak $25 \%$. Disamping itu, terdapat pedagang dengan pengetahuan keamanan pangan dalam kategori baik yang menggunakan boraks sebanyak 12,5\%. Berdasarkan hasil uji secara statistik antara variabel pengetahuan dengan penggunaan formalin dan boraks menunjukkan hasil $p$ value $>0,05$ yaitu $p$ 0,509. Hal ini menunjukkan tidak ada hubungan yang bermakna antara pengetahuan pedagang jajanan anak sekolah dengan penggunaan formalin dan boraks di SD Negeri wilayah Pedurungan kota Semarang tahun 2018. Pengetahuan merupakan hasil dari tahu dan terbentuk setelah seseorang melakukan pengeinderaan terhadap suatu obyek tertentu. Tahu diartikan hanya sebagai memori yang telah ada sebelumnya setelah mengamati sesuatu. Tahu merupakan tingkatan pengetahuan yang paling rendah. Seseorang yang hanya mengetahui suatu informasi, belum tentu berperilaku sesuai informasi tersebut ${ }^{10}$.

Penggunaan bahan tambahan makanan masih perlu mendapatkan perhatian baik jenisnya maupun ukurannya. Bahan tambahan 
yang boleh digunakan adalah bahan tambahan khusus makanandan ukurannya sesuai dengan yang telah ditetapkan oleh pemerintah dalam Peraturan Menteri Kesehatan Republik Indonesia no. 33 tahun $2012^{11}$.

Pengetahuan responden penelitian ini sebagian besar termasuk dalam kategori baik namun terdapat pedagang yang menggunakan bahan kimia yaitu boraks. Berdasarkan hasil wawancara, pengetahuan keamanan pangan yang diketahui oleh para pedagang tersebut pada umumnya diperoleh dari keikutsertaan penyuluhan kesehatan dari Dinas Kesehatan setempat. Sumber informasi lain bisa secara lisan dari mulut kemulut, namun untuk mengaplikasikan pengetahuan yang telah diperoleh secara lisan tersebut juga sulit, mengingat beberapa hal diantaranya produsen ingin menampilkan dagangannya lebih menarik dengan cita rasa yang tinggi dengan biaya produksi yang rendah ${ }^{11}$. Hal itu menjadi salah satu faktor pedagang menggunakan bahan kimia untuk makanan, faktor lainnya yaitu ketidaktahuan masyarakat, harga bahan kimia yang murah, kemudahan dalam mendapatkan, tekstur produk yang bagus dan tahan lama ${ }^{12}$.

Pengetahuan responden penelitian ini yang termasuk dalam kategori kurang baik namun tidak menggunakan formalin dan boraks dikarenakan terdapat faktor lain yang mempengaruhi perilaku pedagang. Yaitu pengaruh dari pedagang makanan jajanan lain yang tidak menggunakan bahan kimia berbahaya serta pengawasan dan pembinaan yang dilakukan oleh Dinas Kesehatan. Hasil penelitian menunjukkan bahwa 6 pedagang pernah mengikuti penyuluhan kesehatan yang diselenggarakan oleh Dinas Kesehatan.

\section{F. Hubungan Sikap Keamanan Pangan terhadap Penggunaan Formalin dan Boraks}

Sikap pedagang makanan merupakan salah satu faktor yang mempengaruhi perilaku pedagang dalam penggunaan formalin dan boraks. Sikap mengenai penggunaan bahan kimia yang dilarang merupakan hasil perubahan pada pedagang jajanan dan mengalami perubahan terus-menerus menyesuaikan diri dengan kondisi lingkungan.

$$
\text { Pengujian secara statistic }
$$

menggunakan Fisher's Exact antara variabel sikap keamanan pangan dengan penggunaan boraks di SD Negeri wilayah Pedurungan kota Semarang tahun 2018 dapat dilihat selengkapnya pada tabel 8.
Tabel 8. Hasil Analisis Penggunaan Boraks Menurut Sikap Pedagang Jajanan Anak di SD Negeri wilayah Pedurungan tahun 2018

\begin{tabular}{cccccccc}
\hline \multirow{2}{*}{$\begin{array}{c}\text { Sikap Pedagang } \\
\text { Jajanan Anak }\end{array}$} & \multicolumn{3}{c}{\begin{tabular}{c}
\multicolumn{3}{c}{ Penggunaan Formalin dan } \\
Boraks
\end{tabular}} & \multicolumn{2}{c}{ Total } & \multirow{2}{*}{ p } \\
\cline { 2 - 5 } & \multicolumn{2}{c}{ Tidak Ada } & \multicolumn{2}{c}{ Ada } & & & \\
\cline { 2 - 5 } & $\mathbf{n}$ & $\%$ & $\mathbf{N}$ & $\%$ & $\mathbf{n}$ & $\%$ & \\
\hline Tidak Mendukung & 6 & $75 \%$ & 2 & $25 \%$ & 8 & $100 \%$ & \\
Mendukung & 11 & $91,7 \%$ & 1 & $8,3 \%$ & 12 & $100 \%$ & 0,537 \\
Total & 17 & $85 \%$ & 3 & $15 \%$ & 20 & $100 \%$ & \\
\hline
\end{tabular}

Tabel 8 menunjukan bahwa pedagang dengan sikap keamanan pangan dalam kategori tidak mendukung sebagian besar tidak menggunakan formalin dan boraks dalam dagangannya (75\%). Selebihnya pedagang dengan sikap tidak mendukung sebanyak $25 \%$ menggunakan boraks. Disamping itu, terdapat pedagang dengan sikap keamanan pangan dalam kategori mendukung yang menggunakan boraks sebanyak 8,3\%.

Berdasarkan hasil uji secara statistik menggunakan Fisher's Exactantara variabel pengetahuan dengan penggunaan boraks menunjukkan hasil $p$ value $>0,05$ yaitu $p 0,537$. Hal ini menunjukkan tidak ada hubungan yang bermakna antara sikap pedagang jajanan anak sekolah dengan penggunaan boraks di SD Negeri wilayah Pedurungan Kota Semarang tahun 2018.

Sikap pedagang sebagian besar termasuk dalam kategori mendukung namun terdapat pedagang yang menggunakan bahan kimia yaitu boraks karena sikap bukan merupakan satu-satunya faktor yang mempengaruhi perilaku pedagang dalam menggunakan bahan kimia dalam makanan. Penggunaan boraks pada makanan jajanan digunakan oleh pedagang bertujuan untuk meningkatkan daya awet makanan dan menciptakan tekstur kenyal yang diharapkan. Boraks mudah didapatkan di masyarakat, dipasaran boraks dikenal dengan sebutan bleng, pijer atau gendar. Harganya relatif terjangkau sehingga membuat produsen akan berpikiran mendapatkan keuntungan yang sebesar-besarnya jika menggunakan boraks pada produk makanannya ${ }^{13}$. Faktor lain yang memungkinkan timbulnya perilaku adalah akses yang mudah dalam mendapatkan bahan kimia berbahaya seperti boraks yang bisa dibeli di warung maupun pasar dekat tempat pedagang jajanan berdagang ${ }^{14}$. Hal ini tentunya perlu mendapatkan perhatian dan penanganan lebih lanjut yang serius dari pihak-pihak yang berwenang, karena dampak yang dapat ditimbulkan akibat mengkonsumsi bahan- 
bahan kimia berbahaya tersebut sangat merugikan. Konsumsi boraks secara terus menerus dapat mengganggu gerak pencernaan usus, kelainan pada susunan saraf, depresi dan kekacauan mental $^{15}$.

Sikap pedagang yang termasuk dalam kategori tidak mendukung namun tidak menggunakan formalin dan boraks karena terdapat faktor lain yang mempengaruhi perilaku pedagang diantaranya kepercayaan pedagang, sosial, budaya dan ekonomi pedagang, pengalaman dan pedagang lain dan pengawasan yang dilakukan oleh Dinas Kesehatan dan BPOM ${ }^{15}$.

\section{KESIMPULAN}

Tidak ada hubungan baik pada variabel pengetahuan dan sikap dengan penggunaan formalin dan boraks di SD Negeri wilayah Pedurungan tahun 2018 namun ditemukan adanya jajanan yang mengandung boraks pada jajanan tempura, cilor dan somay wilayah Pedurungan pada tahun 2018.

\section{SARAN}

Berdasarkan hasil penelitian maka untuk menindak lanjuti hasil pernelitian ini memberikan usulan kepada BPOM agar dilakukan pembinaan dan penyuluhan untuk pedagang dan siswa siswi SD Negeri khususnya mengenai bahan tambahan pangan pada pedagang jajanan anak sekolah di SD Negeri wilayah Pedurungan serta bagi peneliti lain yang akan melakukan penelitian serupa sebaiknya perlu dilanjutkan dengan faktor-faktor lain dari faktor enabling dan faktor reinforcing.

\section{DAFTAR PUSTAKA}

1. Badan Pengawas Obat \& Makanan. Cara, Tata Sarana dan Pemeriksaan Pangan Produksi Rumah Tangga \& Industri. 2012;2015:1-28.

2. Alamsyah Emrald I. Ini Tantangan Ganda Keamanan di Indonesia. 2015.

3. Effendi S. Teknologi Pengolahan dan Pengawetan Makanan. Bandung: Alfabeta; 2012.

4. Asrianti. Ini Bahaya Formalin Dalam Makanan. Health. 2016 Sep 11;13.

5. Novita S, Adriyani R. Tingkat Pengetahuan dan Sikap Pedagang Jajanan tentang Pemakaian Natrium Siklamat dan Rhodamin B. Promkes. 2008;1:192-200.

6. Fajar I, Isnaeni, Pujirahaju A, Amin I, Sunindya R, Aswin A, et al. Statistika uji Praktisi Kesehatan. Yogyakarta: Graha IImu; 2009.

7. Badan Pengawas Obat dan Makanan. Bahan Berbahaya Yang Dilarang Untuk Pangan [Internet]. 2006 [cited 2018 Mar 26].
8. Mahdi C. Mengenal Bahaya Formalin, Borak Dan Pewarna Berbahaya Dalam Makanan. Malang; 2012.

9. Kenali Ciri-Ciri Zat Berbahaya Pada Makanan [Internet]. 2011. Available from: www.suaramedia.com

10. Notoatmodjo, Soekidjo. IImu Perilaku Kesehatan. PT Rineka Cipta : Jakarta, 2010.

11. Aminah S, Hidayah N. Knowledge of Food Security of The Street Food Eat Sellers in School Country Side. J Litbang Muhamadiyah Univ Semarang. 2004;18-25.

12. Handayani S. Analisis Faktor Yang Mempengaruhi Pedagang Makanan Jajanan Dalam Pemakaian Pewrana Berbahaya Di Lingkungan Sekolah Dasar Kecamatan Klaten Tengah. Motorik. 2009;4.

13. Teguh. Identifikasi Boraks pada Makanan [Internet]. 2012. Available from: www.putraindonesiamalang.or.id/identifikasi boraks pada makanan.html

14. Pramastuty, Lailya. Raharjo, Mursid. Hanani, Yusniar. Faktor-Faktor Yang Mempengaruhi Keberadaan Zat Pewarna Dan Pengawet Terlarang Pada Makanan Jajanan Di PasarPasar Tradisional Kota Semarang. Jurnal Kesehatan Masyarakat, 2017. Vol 5 (1).

15. Saparinto C, Diana H. Bahan Tambahan Pangan. Yogyakarta: Kanisius; 2006. 